
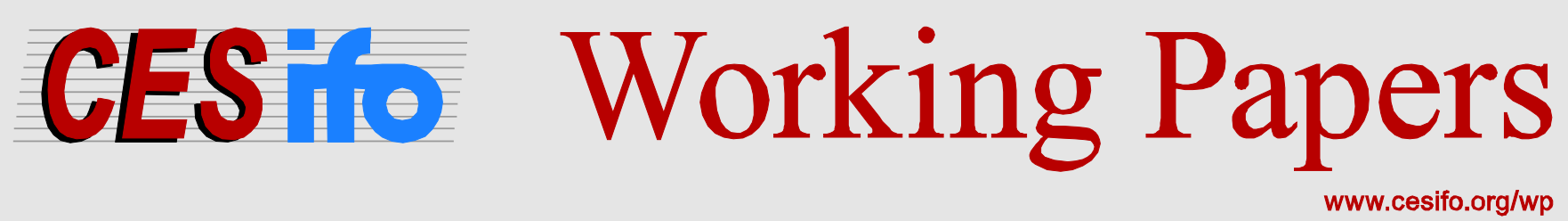

\title{
Social Unrest in the Wake of IMF Structural Adjustment Programs
}

\author{
Caleb Stroup \\ Ben Zissimos
}

CESIFO WORKING PAPER NO. 4211

CATEGORY 3: SOCIAL PROTECTION

APRIL 2013
An electronic version of the paper may be downloaded
- from the SSRN website:
- from the RePEc website:
- from the CESifo website:
www.SSRN.com
Www.RePEc.org
www.CESifo-group.org/wp

\section{CESifo}




\title{
Social Unrest in the Wake of IMF Structural Adjustment Programs
}

\begin{abstract}
This paper proposes an answer to the question of why social unrest sometimes occurs in the wake of an IMF Structural Adjustment Program (SAP). Under certain circumstances, partly determined by a country's comparative advantage, a nation's elite may have an incentive to make transfers to the rest of society through government employment in order to quell social unrest. But under an SAP, the elite are constrained from making such transfers and consequently social unrest may arise. The paper proposes a framework from which a prediction can be made about the circumstances under which social unrest can be expected to occur. It then takes this prediction to the data and finds empirical support for it.
\end{abstract}

JEL-Code: D300, D740, F100, O120, P140.

Keywords: institutions, International Monetary Fund (IMF), social unrest, structural adjustment, trade integration.

\author{
Caleb Stroup \\ Department of Economics \\ Grinnell College \\ USA - Grinnell, IA 50112 \\ stroupca@grinnell.edu
}

\author{
Ben Zissimos \\ Department of Economics \\ University of Exeter Business School \\ UK - Exeter EX4 4ST \\ b.zissimos@exeter.ac.uk
}

March 30th, 2013

We would like to thank Emily Blanchard, Rick Bond, Arye Hillman and Isleide Zissimos for useful conversations about this paper. We are grateful for comments from two anonymous referees that greatly improved the exposition. This paper also benefitted from comments on a progenitor by participants at the CES-ifo conference on The Economics of Conflict - Theory and Policy Lessons. Financial support from CES-ifo is gratefully acknowledged. 


\section{Introduction}

The Structural Adjustment Programs (SAPs) of the International Monetary Fund (IMF) have long been criticized for allegedly worsening wellbeing in the countries where they are imposed. ${ }^{3}$ It is claimed that they may reduce welfare, exacerbate income inequalities, and ultimately provoke social unrest as those in society hit by the SAPs lash out in response. Stiglitz (2002) provides an account of the possible effects of SAPs when he writes: "For decades, people in the developing world have rioted when the austerity programs imposed on their countries [by the IMF] proved to be too harsh..." (p.3). "For the peasants in developing countries who toil to pay off their countries' IMF debts or the businessmen who suffer from higher value added taxes upon the insistence of the IMF, the current system run by the IMF is one of taxation without representation ... Left with no alternatives, no way to express their concern, to press for change, people riot" (p.20). Yet despite widespread acknowledgement that there is a link between the imposition of SAPs and the occurrence of social unrest, we still do not have a clear understanding of the forces that drive this link.

The purpose of this paper is to try to understand the relationship between the imposition of SAPs and the occurrence of social unrest. We identify a well-defined set of circumstances under which the imposition of an SAP can be expected to lead to social unrest and find support for this in the data. Our testable prediction is that if a country has an SAP, it will also tend to experience social unrest if it has a comparative advantage in primary products and at the same time undergoes deeper (i.e. greater/increased) trade integration.

This prediction builds on an analytical framework developed and tested empirically in our prior work, Stroup and Zissimos (2011, henceforth SZ). Since the present paper builds on that paper, it is worth reviewing the key features of the framework we set up in SZ. In that previous paper, we show how the effects of a ruling elite's attempts to maintain political stability on efficiency depend on underlying factor endowments.

\footnotetext{
${ }^{3}$ SAPs have two components. One is the extension of loans, coupled with possible multilateral renegotiation to reduce a country's total debt obligations. The second is the adjustment of a country's policies which is aimed at increasing economic efficiency and growth, and with it a country's ability to meet its debt obligations (Boughton 2001). Elsewhere in the literature, the term 'Structural Adjustment Loan' (SAL) is used equivalently to our use of the term SAP.
} 
If a country's endowments are such that it has a comparative advantage in primary products, and if the elite predominantly owns the land used to produce primary products, trade integration is potentially destabilizing. The reason is because the conjunction of a comparative advantage in primary products and trade liberalization raises the value of primary products and hence the land on which they are produced. This raises the incentives for the rest of society to try to seize control of the elite's land in a popular uprising. This in turn mandates an increase of government spending in general and government employment in particular, through which the elite make transfers to the rest of society in a bid to maintain political stability. ${ }^{4}$ The general-equilibrium effects of increasing government employment are to draw resources away from the more efficient manufacturing sector, potentially reducing overall economic efficiency. If a country's endowments are such that it has a comparative advantage in manufactures then the elite's incentives are reversed, and trade integration enhances economic efficiency.

The testable prediction that arises from the theoretical model in that earlier paper is as follows. An increase in trade integration leads to an increase in government employment in countries with a comparative advantage in primary products, but to a decrease in government employment in countries with a comparative advantage in manufactures. Our econometric analysis in that paper, which conditions on a variety of country-specific factors and persistence in the size of government, provides support for this prediction across a variety of specifications.

The testable prediction of the present paper is then derived as follows. The conditionality of an SAP requires a country to liberalize trade while at the same time undertaking privatization, involving a process of rolling back the state and reducing government employment. ${ }^{5}$ But in the context of the framework set out by SZ, if the country has a

\footnotetext{
${ }^{4}$ Increasing the size of government may not be the most efficient way to make transfers aimed at maintaining political stability, with alternative more far-reaching measures such as land reforms likely to be more efficient. However, there appears to be anecdotal evidence to suggest that government employment is a relatively manipulable device through which transfers can be made quickly if the need arises, in contrast to land reforms which tend to proceed relatively slowly. For example, The Economist (2011) documents several instances where ruling elites rapidly made transfers to the rest of society through government employment in their attempts to quell the wave of uprisings in the Middle East known as the Arab Spring.

${ }^{5}$ SAPs also typically require stabilization of the macroeconomic environment, principally through the use of monetary policy. That aspect of SAPs is beyond the scope of the present analysis. See Williamson (1989) for the original statement of the "Washington Consensus" on policy reform.
} 
comparative advantage in primary products, the rest of society has an incentive to mount a revolution precisely in situations where trade liberalization occurs and so inequality increases. Without the constraints imposed by an SAP, the elite would respond by increasing government employment in order to undertake redistribution and thus defuse the incentive for political unrest. But the constraints imposed by the SAP to privatize and roll back the state constrain the elite in their ability to undertake redistribution through expansion of government employment. This results in the rest of society's incentive to mount a revolution remaining undefused. Therefore, the testable prediction of the present paper is a surprising implication of SZ that we did not pursue in the earlier paper. It is that when a country has a comparative advantage in primary products, trade liberalization in the presence of an SAP makes the country 'vulnerable to revolution.'

How do we capture vulnerability to revolution in the data? The lead up to a revolution usually unfolds gradually. There is often a protracted period between when the incentive to mount a revolution arises and when a revolution actually occurs, assuming the ruling elite do successfully avert its occurrence. Ellis and Fender (2010) have modeled this process as an information cascade whereby members of the rest of society signal to one another their desire to mount a revolution. Adapting Ellis and Fender's framework to the present context, the types of social unrest that have arisen in response to SAPs may be construed in terms of such signals: for example strike activity, violent demonstrations, large scale peaceful protest. We will refer to these forms of social unrest as indicating vulnerability to revolution. ${ }^{6}$

The specific process through which a ruling elite may defuse vulnerability to revolution is as follows. Once a situation arises where a country may become vulnerable to revolution, there is a window of opportunity within which the elite can respond with measures, such as increasing government employment, that restore the status quo. The elite accept the constraints on government employment imposed by an SAP, through which vulnerability to revolution may arise, because it is usually the elite who have most to gain from the SAP's successful imposition. The reason is because the SAP generally de-

\footnotetext{
${ }^{6}$ The interpretation that social unrest indicates vulnerability to revolution may seem extreme given that we have developed countries in our dataset where revolution is rarely observed. Here we are taking the position that these countries can in principle be vulnerable to revolution but that a well-functioning democracy has better mechanisms for defusing this vulnerability including, as a final backstop, transfer of power through the ballot box.
} 
termines a country's future access to world capital and goods markets, which the elite make use of. To the extent that the rest of society is unable to access capital markets and unable to afford traded goods, its benefit from the imposition of an SAP is less clear. So a country's elite is likely to support the imposition of an SAP to the fullest extent possible while the rest of society may be against it. But the elite will have an incentive to relax its terms if the SAP appears to be creating vulnerability to revolution. Governments generally have sufficient leeway, and in any case the sovereignty, to renege on the terms of an SAP if needed (Easterly 2005).

We are able to obtain measures of various types of social unrest across a broad range of countries from the Cross National Time Series Data Archive (CNTS). And we proxy trade liberalization using a standard measure of economic openness. Our results show that, for a country that has a comparative advantage in primary products and an SAP in place, an increase in economic openness relative to the size of government does increase vulnerability to revolution and hence the likelihood of social conflict. This relationship holds for six out of eight measures of social conflict in the CNTS. We take this to represent support in the data for our framework's prediction. As we will discuss below, this observed relationship is robust to a broad range of salient alternative hypotheses.

The key difference between the present paper and SZ can be understood in terms of differences in the time-frame of the analysis. An underlying assumption in SZ is that sufficient time passes within a period that the elite are able to resolve any vulnerability to revolution using adjustments to government employment. In that paper, social unrest is not actually observed on the equilibrium path. In the present paper, the time-frame within a period is assumed to be sufficiently short that vulnerability to revolution may indeed arise, reflected in social unrest. This difference in approach makes it possible for us to study the causes of social unrest in the present paper, where this was not possible in SZ.

The past literature in economics evaluating the impact of IMF SAPs has tended to focus overwhelmingly on their impact on economic growth, not least because the stated intention of SAPs is to improve it. The results from a wide range of studies, by the IMF and by independent researchers, have found positive, zero and negative effects of IMF lending on growth. Easterly (2005) first reviews the literature and reports it to be 
inconclusive, and then undertakes his own analysis to show a significantly negative effect of SAPs on economic growth. There is similarly mixed evidence of SAPs on policies (see the survey by Killick, Gunatilaka and Marr 1998). There is a small academic literature on the effects of SAPs on conflict, which is nicely summarized by Guimond (2007). This literature studies the efficacy of SAPs in countries that have had social conflict in the past, focusing on civil war, at reducing the likelihood that conflict will break out again in the future. As with the literature on the impact of SAPs on growth, conclusions are varied with no clear pattern emerging. ${ }^{7}$

There is also a literature in political science and sociology on how structural adjustment or the policies attributed to IMF conditionality affect social unrest. Walton and Seddon (1994) were among the first to systematically explore the significant fluctuations in commodity prices that ultimately gave way to the first Latin American debt crisis of the 1980s, prompting intervention by the IMF in a bid to restore economic and political stability. They document that it was the wave of unrest that came about as a result of these events that prompted the term 'IMF Riot'. Similarly to the literature in economics on the relationship between IMF conditionality and growth, the line of enquiry exploring IMF conditionality and conflict has largely been inconclusive; see Hartzell, Hoddie and Bauer (2010), who find that IMF structural adjustment programs increase the likelihood of civil war, and the literature cited therein. Hartzell et al is related to our paper in that the discussion emphasizes how IMF conditionality creates gainers and losers while at the same time constraining the government's ability to make transfers that could mitigate social unrest. But neither they nor the literature that they cite focus on comparative advantage as a way to distinguish between the circumstances under which the rest of society is likely to resort to social unrest as we do here. The key novel point we are making, therefore, is that comparative advantage plays a decisive role in predicting the circumstances under which IMF conditionality leads to social unrest.

\footnotetext{
${ }^{7}$ Structural adjustment loans from the World Bank also have conditionalities attached to them and there is a literature evaluating these as well. We focus on IMF SAPs because they are associated more closely with the occurrence of social conflict. This is perhaps because IMF SAPs are tied more tightly to balance of payments crises which are likely to require immediate constraints on entitlement spending that in turn increase inequality and provoke social unrest. World Bank lending has been more associated with long term structural adjustment, although since the 1980s IMF and World Bank lending have been used in conjunction with one another, the former maintaining its focus on adjustments to recover from balance of payments crises, the latter on longer term objectives of policy reform (Boughton 2001, Easterly 2005).
} 
The rest of the paper is structured as follows. Section 2 provides details of the empirical set-up. Section 3 describes the data in more detail. Section 4 presents the estimation results and Section 5 discusses the extent to which the estimates might be given a causal interpretation. Conclusions are drawn in Section 6.

\section{Empirical Set-up}

We now set out an econometric formalization of the economic framework described informally in the previous section. In SZ, an elite maintains the status quo by ensuring that a 'no-revolution constraint' (NRC) binds. From a situation where the NRC is binding, it would fail to bind if the country had a comparative advantage in primary products and trade integration deepened. The elite would then make the NRC bind again by increasing government employment. In any country $i$ and period $t$, the NRC depends directly on the elite's choice variable, which is the size of government employment, $B_{i t}$, as well as on trade integration, $O_{i t}$, and comparative advantage, $C_{i} .{ }^{8}$ We can express the reduced form of the NRC as $\psi\left(C_{i}, O_{i t}, B_{i t}\right)$.

We will say that the country in question becomes vulnerable to revolution when its NRC fails to bind. The NRC fails to bind if $0<\psi\left(C_{i}, O_{i t}, B_{i t}\right)$. In this state, members of the rest of society signal to one another that they would like to engage in a revolution by undertaking various types of social unrest. To formalize this, denote the probability of social unrest in country $i$ and period $t$ by $c_{i t}$. Given that idiosyncratic income shocks, $\varepsilon_{i t}$, influence the probability of social unrest, we can express the probability of social unrest as follows:

$$
c_{i t}=\left\{\begin{array}{l}
0 \text { if } 0 \geq \psi\left(C_{i}, O_{i t}, B_{i t}\right)+\varepsilon_{i t} \\
1 \text { if } 0<\psi\left(C_{i}, O_{i t}, B_{i t}\right)+\varepsilon_{i t}
\end{array}\right.
$$

Consider a country that has a comparative advantage in primary products $\left(C_{i}=1\right)$. For $C_{i}=1$, increased trade integration increases vulnerability to revolution; $\partial \psi / \partial O_{i t}>$ 0 . At the same time, an expansion of government employment has an offsetting effect; $\partial \psi / \partial B_{i t}<0$. The opposite effects hold for countries with a comparative advantage in manufactures, where the term 'manufactures' will be used as a short-hand for 'all

\footnotetext{
${ }^{8}$ For the purposes of our econometric implementation, trade integration is treated as exogenous. See the next section for details.
} 
goods other than primary products'. An unconstrained elite will usually be able to offset changes in trade integration with changes in government employment, thus heading off social unrest. ${ }^{9}$ This specification captures in a simple way the econometric framework of SZ but it does not allow for the increased likelihood of social unrest if the country is bound by an SAP that is the concern of the present paper.

Where an SAP is imposed, an elite may be constrained from increasing government employment, at least in the first instance, thus creating vulnerability to revolution and increasing the probability of social unrest. Vulnerability comprises three necessary conditions for the NRC to fail. First, a country must have a comparative advantage in primary products $\left(C_{i}=1\right)$. Second, the country must have an SAP, brought about by the occurrence of a balance of payments $(\mathrm{BOP})$ crisis $\left(B O P_{i t}=1\right)$. Finally we require an inverse relationship between trade integration and the size of government employment, which is given by the fact that the country has a comparative advantage in primary products. This is formalized by the function $f\left(O_{i t}, B_{i t}\right)$, whereby $\partial^{2} f_{i t} / \partial O_{i t} \partial B_{i t}<0$. We thus measure vulnerability to revolution as follows:

$$
v_{i t}=\left\{\begin{array}{c}
0 \text { if } B O P_{i t}=0 \\
f\left(O_{i t}, B_{i t}\right) \text { if } C_{i}=1 \& B O P_{i t}=1 .
\end{array}\right.
$$

This setup suggests a straightforward estimating approach via the following equation:

$$
c_{i t}^{j}=\beta_{1}^{j} v_{i t}+\Theta_{i t}+a_{i}+\tau_{t}+\varepsilon_{i t},
$$

where the variables are defined as follows: $c_{i t}^{j}$ is a specific measure of social unrest such as strike activity or the occurrence of violent demonstrations; $v_{i t}$ indexes the vulnerability to revolution in terms of the probability that the NRC may fail to bind; $\Theta_{i t}$ is a vector of time-varying country-specific controls; $a_{i}$ is a vector of country-specific fixed effects; $\tau_{t}$ are year effects. ${ }^{10}$

\footnotetext{
${ }^{9}$ In fact there exist extreme conditions under which the elite will not be able to use government employment to maintain the status quo. We abstract from them here but discuss them at length in SZ.

${ }^{10}$ Although a large literature takes the incidence of BOP crises and SAPs as given, there is a growing literature that attempts to instrument SAPs conditional on BOP incidence. While this approach may be useful for studying, for example, the relationship between SAPs and growth, it would not, in our context, fully address the identification concern since the usual instruments (e.g. political proximity to major shareholders at the IMF, voting behavior at the United Nations) will also be correlated with any potentially time-varying country-specific institution. For further discussion, see, for example, Bird and Rowlands (1991, 2002), World Bank (1992, 1998), Conway (1994), Alesina and Dollar (2000), Burnside and Dollar (2000), Barro and Lee (2005), Dreher and Jensen (2007), and Kilby (2009).
} 
It might be suggested that we implement (2.3) using a binary response model such as logit or probit by imposing the assumption of normally distributed errors. However, fixed effects in such frameworks must be computed individually, leading to the incidental variables problem in which the number of parameters increases in proportion to the number of countries, thus generating inconsistent parameter estimates. Thus, we take the simplest possible approach and estimate (2.3) using a linear-probability model estimated via OLS, which allows for feasible computation of individual country fixed effects. Our focus is not on the precise marginal effects of vulnerability to social unrest but rather the presence or absence of the predicted effect. Therefore, we view the robustness conferred by using country-specific fixed effects as strongly outweighing the requirement that estimated marginal effects be interpreted as a linear approximation of the true effects.

\section{Data}

To construct the dataset for this study, we combined the dataset from SZ with the Cross National Time Series (CNTS) dataset to provide measures of economic activity in conjunction with indicators of domestic social unrest. The measures of domestic social unrest in CNTS are as follows (followed by an abbreviation in parentheses): ${ }^{11}$ (1) politically motivated assassinations (assassinations); (2) a strike of one thousand or more industrial workers (strikes); (3) armed activity by independent bands of citizens or irregular forces aimed at the overthrow of the present regime (armed activity); (4) a rapidly developing situation that threatens the downfall of the present regime (threatened regimes); (5) systematic elimination of opposition politicians by jailing or execution (opposition elimination); (6) violent demonstration or clash of more than one hundred citizens involving the use of physical force (violent demonstrations); (7) any actual or attempted illegal or forced change in the top government elite including armed rebelion (revolution - pos. attempted); (8) any peaceful public gathering of at least one hundred people for the purpose of voicing opposition to government policies or authority (peaceful demonstrations). For each of the eight measures, indexed by $j=1 \ldots 8$, we construct a dummy variable that takes a value of 1 if, for a particular country in a particular year, there is an occurrence of social unrest.

\footnotetext{
${ }^{11}$ See the footnote of Table 3 for more extensive descriptions of each of the measures of social conflict.
} 
We measure government employment, $B_{i t}$, using the log of annual data for central government spending on wages and salaries (1972-2008 in millions of real US dollars) from the International Monetary Fund's (IMF's) Government Finance Statistics database. A full list of countries is given in Table $1 .{ }^{12}$

We employ the measure of revealed comparative advantage $(R C A)$ due to Balassa (1965), and construct it from World Bank trade flows. ${ }^{13}$ Measurement of trade integration presents us with a difficulty when it comes to estimation. On the one hand, our discussion of IMF/SAP conditionality in the Introduction suggests that tariffs would be the appropriate way to measure this. After all, the Washington Consensus calls for trade liberalization through adjustments to economic policy. However tariffs are also understood to be endogenously determined, making them unsuitable for use on the right hand side of a regression. Consequently, we measure trade integration with the gravity-based measure used by Rose (2004), and Hijzena, Gorg and Munchin (2008) among others, which is the distance-weighted average of all trading partners' GDPs. ${ }^{14}$ First define $Y_{i t}$ as country $i$ 's GDP in year $t$ expressed in millions of constant dollars and let $\delta_{i j}$ be the distance between countries $i$ and $j$. This measure of trade integration is $O_{i t}=\sum_{j \neq i} Y_{j t} / \delta_{i j}$. Unlike other measures of trade integration such as tariffs and the terms of trade, which are clearly

\footnotetext{
${ }^{12}$ Since our estimation procedure identifies parameters using only within-variation, we need a sample whose variables exhibit significant variation across time. Fortunately, both trade integration and central government employment varied significantly during our sample period for many countries. An alternative would have been to employ data from the International Labor Organization. However, for our purposes, these data are not nearly as comprehensive in their coverage across countries as the IMF series, especially prior to 1995.

${ }^{13}$ Let $X_{i k t}$ be country $i$ 's exports of product category $k$ to the rest of the world in period $t$, and let $X_{i \omega t}$ be total exports from country $i$ to the rest of the world within a set of product categories $\omega . X_{n k t}$ is the sum of all other countries' (i.e. $j \neq i$ ) exports in product category $k$, and $X_{n \omega t}$ are total world exports in the set of product categories. Then $R C A_{i k t}=\left(X_{i k t} / X_{i \omega t}\right) /\left(X_{n k t} / X_{n \omega t}\right)$. Following the standard approach, country $i$ has a revealed comparative advantage in product $k$ if and only if $R C A_{i k t}>1$. In our sample, $R C A$ is stable over time, allowing use of the mode across years as our measure of a country's comparative advantage. Given that we are making cross-country sector comparisons, we also require a correspondence between the Balassa index and pre-trade relative prices; the Hillman condition must hold (see Hillman 1980). In a dataset of 165 countries from 1970-1998, Hinloopen and van Marrewijk (2008) have shown that violations of the Hillman condition are rare after 1984 but prior to 1984 violations do occur relatively frequently for countries whose exports are concentrated on a small number of sectors. Our main results are slightly stronger when we truncate the data in 1984, which provides support for our hypothesis and for the empirical relevance of the Hillman condition.

${ }^{14}$ Goldberg, Khandelwal, Pavcnik and Topalova (2010) argue in their study of India that in the event of an unanticipated BOP crisis and SAP, the tariff reforms mandated by the program may be regarded as exogenous. However, this argument would only apply in our dataset to the minority of countries in any given period that were constrained by SAPs. Therefore, we cannot use the approach advocated by Goldberg et al.
} 
endogenous, most countries' governments have limited if any influence over (the distanceweighted average of) their trading partners' GDPs. Therefore, variation in $O_{i t}$ plausibly extracts identifying variation in relative prices.

The variable $v_{i t}$ is measured as follows. First, $v_{i t}=0$ when either $C_{i}$ or $B O P_{i t}$ are equal to zero and $v_{i t}=f\left(O_{i t}, B_{i t}\right)$ otherwise, so that $v_{i t}=f\left(O_{i t}, B_{i t}\right) \times C_{i} \times B O P_{i t}$, where the latter two are binary variables. Second, since our fixed-effects estimation procedure identifies model parameters off of variation within a country across time, we approximate $f\left(O_{i t}, B_{i t}\right)$ with $O_{i t} / B_{i t}$. This satisfies the requirement (specified above) that $\partial^{2} f_{i t} / \partial O_{i t} \partial B_{i t}<0$.

Balance-of-payments crises are likely to induce social unrest in a variety of ways not directly tied to the theoretical model presented in SZ. To control for these, we also include $B O P_{i t}$ by itself in the regressions. Similarly, we include $C_{i}, B_{i t}$ and $O_{i t}$ in levels in all equations, along with all pairwise interactions among these variables. We also include the full vector of interaction combinations within the set $\left\{O_{i t}, B_{i t}, C_{i}, B O P_{i t}\right\}$; this will be referred to in the tables as the 'interaction vector'. Finally, we control for observable determinants of total government employment that may be correlated with trade integration, comparative advantage, and BOP crises. For example, larger economies may tend to have both a comparative advantage in manufacturing and to experience larger responses of total government employment to changes in trade integration. If larger economies tend to be more developed, they may also be less subject to BOP crises. To capture these economy-size effects, we include total GDP expressed in millions of US dollars $\left(G D P_{i t}\right)$. Similarly, countries with higher incomes may tend to have higher wage rates and thus higher central government spending on wages and salaries. This may vary systematically by comparative advantage to the extent that countries with a comparative advantage in manufacturing have higher average wage rates than countries with a comparative advantage in primary products. An ideal measure would be middle class wage rates or the minimum wage. Since no such data exist at the annual level for a wide variety of developing countries, we use GDP per capita in thousands of dollars $\left(G D P_{i t} / N_{i t}\right)$ instead. These two series came from the Penn World Tables. Table 2 summarizes the unrest measures broken down by the incidence of unrest. 


\section{Empirical Results}

Table 3 presents results from a simple regression of each of our eight measures of social unrest (introduced at the beginning of Section 3) on $B O P_{i t}$. Recall that $B O P_{i t}$ captures BOP crises that involved imposition of an SAP. The estimated coefficients are positive and significant at conventional levels across six out of the eight measures, confirming that SAPs are indeed broadly correlated with the occurrence of social unrest, as generally suspected.

In Table 4, we introduce the measure of vulnerability to revolution, $v_{i t}$, to the specification. From the top row we can see that inclusion of the vulnerability measure leads to substantial attrition in the predictive power of $B O P_{i t}$; in this case it has no predictive power for assassinations (column 1), threatened regimes (column 4), opposition elimination (column 5), and revolutions (column 7). This indicates that the observed correlation presented in Table 3 between $B O P_{i t}$ and our eight measures of social unrest is likely to reflect omitted country-specific variables and, in particular, the omission of $v_{i t}$ itself. Turning to the coefficient on $v_{i t}$, we can see that for all but two measures the estimated coefficients are negative; in three cases they are negative and significant. In only one case, that of armed activity (column 3 ) is the estimated coefficient positive and significant.

As discussed above, the presence of country-specific factors simultaneously correlated with $B O P_{i t}$ and $v_{i t}$ could lead to biased estimates of the true effect of these variables on the incidence of social unrest. To address this possibility, in Table 5 we incorporate country-specific fixed effects and the interaction vector. Looking across the first row, which presents the estimated coefficients on $v_{i t}$, we can see that inclusion of these countryspecific factors leads to a dramatic change in the estimated coefficients so that $v_{i t}$ is positive and statistically significant at conventional levels for all but two of our measures of social unrest. The exceptions are threatened regimes (column 4, which is only significant at the 10 percent level) and peaceful demonstrations (column 8). This indicates that, given a BOP crises and imposition of SAP in a country with a comparative advantage in primary products, a deepening of trade integration relative to the size of government did indeed increase the likelihood of social unrest. For assassinations (column 1) and revolutions (pos. attempted) (column 7), the coefficient on $B O P_{i t}$ is positive and significant at the 
five and one percent levels respectively. This suggests that, for these measures of social unrest, a BOP crises and SAP significantly increases the likelihood of social unrest as we might expect.

In Table 6, we add GDP and GDP per capita to the specification. Inclusion of these variables leads the coefficient on $v_{i t}$ to be slightly smaller in magnitude, even though GDP and GDP per capita have no predictive power themselves. This is not surprising since both variables are highly correlated with the time-invariant fixed effects that are present in these specifications. None of the variables have explanatory power for peaceful demonstrations (column 8), possibly because this type of protest is more associated with developed countries where BOP crises accompanied by SAPs are a much rarer occurrence in our dataset.

\section{Discussion}

The estimates obtained from (2.3) are consistent with the underlying causal channel proposed by SZ. We now discuss whether these findings might also be consistent with other salient alternative hypotheses. Of particular importance is that we have controlled for variables that are thought to drive unrest. For example, liberalization by itself may lead to unrest, so we have included $O_{i t}$ in the regressions to control for this fact. Similarly, reductions in government employment may lead to unrest, so we have included $B_{i t}$ by itself in all regressions. As observed in numerous studies that examine the effect of SAPs, the introduction of these conditionalities may be driven by unobserved social unrest, so we control for this by including $B O P_{i t}$ in our regressions. Similarly, per-capita GDP can be seen as a broad outcome variable that reflects institutions broadly defined (Lipset 1960, Hall and Jones 1999, Dollar and Kraay 2003, Easterly and Levine 2003, Glaeser, La Porta, Lopez-de-Salines and Shleifer 2004), and we have controlled for per-capita GDP in the regressions.

Country-specific fixed effects account for arbitrary persistent idiosyncratic effects on the incidence of social unrest. Since one might believe the observed correlation between vulnerability to revolution and unrest to be driven by intertemporal changes in the propensity of social unrest, we have included year effects in all regressions. Additionally, 
there are in principle many complementary effects on social unrest driven by interactions among the components of $v_{i t}$, such as the possibility that natural resource intensive countries that receive SAPs are more unrest-prone relative to others. To account for these types of influences we have included the full set of interaction permutations between the components of $v_{i t}$ and $\left\{O_{i t}, B_{i t}, C_{i}, B O P_{i t}\right\}$.

Our having controlled for these factors implies that an alternative theory (i.e. an omitted variable simultaneously positively correlated with $v_{i t}$ and social unrest) would need to simultaneously influence openness, comparative advantage, government spending on wages and salaries, and the offering of an SAP to the country concerned while at the same time not being captured by persistent country-specific or time-specific factors. At the same time, without a persuasive structural model or instruments for all of $\left\{O_{i t}, B_{i t}, C_{i}, B O P_{i t}\right\}$, one cannot rule out the possibility that arbitrary omitted variables do not drive the observed correlation between $v_{i t}$ and unrest. Nevertheless, we believe that by controlling for these extraneous factors, and thus eliminating them as viable candidates to explain the estimates we obtained, we have increased the probability that the result is driven by the main channel on which we have been focusing.

\section{Conclusions}

This paper has proposed a way of understanding the link between the imposition of SAPs in response to BOP crises and the occurrence of social unrest. In response to the greater inequality brought about by deeper trade integration, if a country has a comparative advantage in primary products, the rest of society has an incentive to mount a revolution whereby it expropriates the elite's assets. In the absence of an SAP, the elite would face no constraints in making transfers to the rest of society in order to restore the status quo. But under the constraints imposed by the SAP, it is not immediately able to do this. Consequently, social unrest breaks out as individuals signal to one another that they would be prepared to mount a revolution. If the elite did nothing the social unrest would escalate to the point where it would culminate in a revolution. But generally speaking, before that point is reached the elite acquiesce and break the conditionality of the SAP, making the transfers required to restore the status quo. 
Our empirical approach has been to show that there is a positive correlation between a country's vulnerability to revolution and the actual incidence of social unrest using a variety of measures. To check the robustness of these correlations, they were conditioned on variables capturing salient alternative hypotheses. Our results provide empirical support for the framework we have laid out. Moreover, they suggest that accounting for institutions through which the elite make transfers to the rest of society in order to restore the status quo, such as the government civil service, is potentially important for understanding the effectiveness of IMF conditionality at inducing policy compliance. Prior accounts of such failure to comply had been attributed to 'lack of commitment by those responsible for implementing the programs'. The present framework goes further in providing a concrete set of circumstances under which such lack of commitment would be rational. In future work it would be useful to test comprehensively for the causality of 'vulnerability to revolution' for the outbreak of social conflict, either by constructing and estimating a structural model of social conflict in this context, or by obtaining instruments for all four components of the vulnerability measure.

A particular concern, both in academic and policy circles, has been why some countries have been provided SAP support for an extended period without any apparent improvement in their macroeconomic situation. As an illustration of this, Easterly (2005) shows in Table 1 of his paper that the average outcome across a range of macroeconomic indicators for the top twenty recipients of SAP support over the period 1980-99 was the same as those for a broad sample of developing countries. His claim is that if SAPs are intended to promote growth, then we should expect to see better performance from countries with SAPs. A second concern is that these countries were supported by SAPs for such a long time without any discernible improvement in performance. The present paper provides a way of understanding this situation. For countries with a comparative advantage in primary products, deeper trade integration (which is mandated under an SAP) may actually cause a country to have to exit from the program due to the social unrest that it provokes, presumably without any resolution to the underlying problems. Repeated attempts to address current account imbalances in this way will repeatedly be met by the same outcome. Until this set of interactions is taken full account of in IMF policy initiatives, further progress on this issue is unlikely to be made. 


\section{References}

[1] Alesina, A., and D. Dollar, (2000); "Who Gives Foreign Aid to Whom and Why? Journal of Economic Growth 5, 33-64.

[2] Barro, R. J. and J.W. Lee, (2005) "IMF-Programs: Who Is Chosen and What are the Effects?" Journal of Monetary Economics 52(7): 1245-1269.

[3] Bird, G., and D. Rowlands, (1991); "IMF Lending: How is it Affected by Economic, Political, and Institutional Factors?" The Journal of Policy Reform 4 (3), 243-270.

[4] Bird, G., and D. Rowlands, (2002); "The Pattern of IMF Lending: An Analysis of Prediction Failures. Journal of Policy Reform Conference on The Role of Multinational Institutions in the International Monetary System, Miami.

[5] Boughton, J., (2001) Silent Revolution: The International Monetary Fund, 19791989. International Monetary Fund, Washington D.C..

[6] Burnside, C., and D. Dollar, (2000); "Aid, Policies, and Growth." The American Economic Review, 847-868.

[7] Conway, P., (1994); "IMF Lending Programs: Participation and Impact." Journal of Development Economics 45, 365-391.

[8] Dollar, David and Aart Kraay. 2003. "Institutions, Trade and Growth." Journal of Monetary Economics 50(1): 133-62.

[9] Dreher, A., and N.M. Jensen, (2007); "Independent Actor or Agent? An Empirical Analysis of the Impact of US Interests on IMF Conditions." The Journal of Law and Economics 50(1): 105-124.

[10] Easterly, W., (2005); "What did Structural Adjustment Adjust? The Association of Policies and Growth with Repeated IMF and World Bank Adjustment Loans." Journal of Development Economics, 76(1): 1-22.

[11] Easterly, W. and R. Levine, (2003); "Tropics, Germs, and Crops: How Endowments Influence Economic Development." Journal of Monetary Economics, 50.1:3-39. 
[12] Economist, The (2011); "Throwing Money at the Street." March 12th 2011: 32.

[13] Glaeser, E., R. La Porta, F. Lopez-de-Silanes, and A. Shleifer, (2004); "Do Institutions Cause Growth?" Journal of Economic Growth 9(3): 271-303.

[14] Goldberg, P.K., A. Khandelwal, N. Pavcnik and P. Topalova (2010); "Imported Intermediates and Domestic Product Growth: Evidence from India." To appear in Quarterly Journal of Economics.

[15] Guimond, M.-F. (2007); "Structural Adjustment and Peacebuilding." International Development Research Centre, Conflict and Development Program Initiative, 20052006.

[16] Hall, R.E. and C.I. Jones. (1999); "Why Do Some Countries Produce so Much More Output per Worker than Others?" Quarterly Journal of Economics, 114(1): 83-116.

[17] Hartzell, C.A., M. Hoddie, and M. Bauer (2010); "Economic Liberalization via IMF Structural Adjustment: Sowing the Seeds of Civil War?" International Organization, 64: $339-356$

[18] Hillman, A.L., (1980); "Observations on the Relation Between 'Revealed Comparative Advantage' and Comparative Advantage As Indicated By Pre-Trade Relative Prices." Weltwirtschaftliches Archiv, 116: 315-21.

[19] Hinloopen, J., and C. van Marrewijk, (2008); "Empirical Evidence of the Hillman Condition for Revealed Comparative Advantage: 10 Stylized Facts." Applied Economics, 40: 2313-2328.

[20] Kilby, C. (2009); "The Political Economy of Conditionality: An Empirical Analysis of World Bank Loan Disbursements. Journal of Development Economics 89(1): 51-61.

[21] Killick, T., R. Gunatilaka and A. Marr, (1998); "Aid and the Political Economy of Policy Change." Routledge Press, London and New York.

[22] Lipset, S.M., (1960); "Political Man: The Social Basis of Modern Politics." New York: Doubleday.

[23] Stiglitz, J. (2002); Globalization and it Discontents, Penguin Books, London, UK. 
[24] Stroup, J.C., and B.C. Zissimos, "Pampered Bureaucracy, Political Stability, and Trade Integration." Vanderbilt University Dept. of Economics Working Paper no. 11-W05.

[25] Williamson, J., (1989); "What Washington Means by Policy Reform." Published in J. Williamson (ed) Latin American Adjustment: How Much Has Happened? Washington, D.C.: Institute for International Economics.

[26] Walton, J., and D. Seddon (1994); Free Markets and Food Riots: The Politics of Global Adjustment. Cambridge, Mass. Blacwell.

[27] World Bank, (1992); "Adjustment Lending and Mobilization of Private and Public Resources for Growth." Country Economics Department, Policy and Research Series, vol. 22. World Bank, Washington, DC.

[28] World Bank, (1998); “Assessing Aid: What Works, What Doesn't, and Why." World Bank Policy Research Report. Oxford University Press, Oxford, UK. 
Table 1. List of Countries

\begin{tabular}{llll}
\hline Albania & Egypt & Lesotho & Portugal \\
Australia & El Salvador & Liberia & Romania \\
Austria & Estonia & Lithuania & Rwanda \\
Barbados & Finland & Luxembourg & Senegal \\
Belarus & France & Madagascar & Seychelles \\
Belgium & Gabon & Malaysia & Singapore \\
Benin & Georgia & Mali & Slovenia \\
Bhutan & Greece & Malta & Spain \\
Bolivia & Guinea & Mauritius & Sri Lanka \\
Brazil & Haiti & Mexico & Sweden \\
Bulgaria & Honduras & Moldova & Switzerland \\
Burundi & Hungary & Mongolia & Tajikistan \\
Cameroon & Iceland & Morocco & Tanzania \\
Chad & India & Netherlands & Thailand \\
Chile & Indonesia & Nicaragua & Togo \\
Colombia & Ireland & Niger & Tunisia \\
Costa Rica & Italy & Norway & Turkey \\
Croatia & Jamaica & Pakistan & Ukraine \\
Cyprus & Kazakhstan & Paraguay & Uruguay \\
Denmark & Latvia & Peru & Vanuatu \\
Djibouti & Lebanon & Poland & Zambia \\
Dominica & & & Zimbabwe \\
\hline
\end{tabular}

Notes: This table provides a list of in-sample countries for which there exists unrest data. The unbalanced panel spans the years 1972-2008. 


\begin{tabular}{|c|c|c|c|c|}
\hline & \multicolumn{2}{|c|}{$B O P_{i t}=0$} & \multicolumn{2}{|c|}{$B O P_{i t}=1$} \\
\hline & Mean & S.D. & Mean & S.D \\
\hline Assassinations & 0.167 & 0.373 & 0.243 & 0.430 \\
\hline Strikes & 0.171 & 0.376 & 0.261 & 0.440 \\
\hline Armed activity & 0.163 & 0.370 & 0.293 & 0.456 \\
\hline Threatened regimes & 0.198 & 0.399 & 0.254 & 0.436 \\
\hline Opposition elimination & 0.090 & 0.287 & 0.161 & 0.368 \\
\hline Violent demonstrations & 0.199 & 0.399 & 0.336 & 0.473 \\
\hline Revolution (pos. attempted) & 0.132 & 0.338 & 0.318 & 0.466 \\
\hline Peaceful demonstrations & 0.271 & 0.444 & 0.376 & 0.485 \\
\hline $\mathrm{N}$ & 1257 & & 279 & \\
\hline
\end{tabular}

This table presents summary statistics for conflict indicators defied at the country-year level. Assassinations takes a value of unity for country $i$ in year $t$ if there is a politically motivated murder or attempted murder of a high government official or politician. The remaining variables are defined analogously. General Strikes takes a value of unity if there is a strike of 1,000 or more industrial or service workers. Guerrilla Warfare takes a value of unity if there is any armed activity, sabotage, or bombings carried on by independent bands of citizens or irregular forces and aimed at the overthrow of the present regime. Major takes a value of unity if there is any rapidly developing situation that threatens to bring the downfall of the present regime. Purges takes a value of unity if there is any systematic elimination by jailing or execution of political opposition within the ranks of the regime or the opposition. Riots takes a value of unity if the country experiences a violent demonstration or clash of more than 100 citizens involving the use of physical force, Revolutions takes a value of unity if there is any illegal or forced change in the top government elite, any attempt at such a change, or any successful or unsuccessful armed rebelion whose aim is independence from the central government. Anti-government demonstrations takes a value of unity if there is any peaceful public gathering of at least 100 people for the primary purpose of displaying or voicing their opposition to government policies or authority. 
Table 3: Social Unrest and IMF SAPs

(1)

\begin{tabular}{|c|c|c|c|c|c|c|c|c|}
\hline$B O P_{i t}$ & $\begin{array}{c}0.073^{*} \\
(0.030)\end{array}$ & $\begin{array}{c}0.089 * * * \\
(0.020)\end{array}$ & $\begin{array}{c}0.133 \\
(0.068)\end{array}$ & $\begin{array}{c}0.056^{* *} \\
(0.020)\end{array}$ & $\begin{array}{c}0.071 * * \\
(0.025)\end{array}$ & $\begin{array}{c}0.144^{* * *} \\
(0.033)\end{array}$ & $\begin{array}{c}0.192^{* * * *} \\
(0.029)\end{array}$ & $\begin{array}{c}0.108^{* * *} \\
(0.017)\end{array}$ \\
\hline Constant & $\begin{array}{c}0.171^{* * *} \\
(0.022)\end{array}$ & $\begin{array}{c}0.173^{* * *} \\
(0.016)\end{array}$ & $\begin{array}{c}0.161^{* * *} \\
(0.034)\end{array}$ & $\begin{array}{c}0.199^{* * *} \\
(0.023)\end{array}$ & $\begin{array}{c}0.091^{* * *} \\
(0.010)\end{array}$ & $\begin{array}{c}0.193^{* * *} \\
(0.025)\end{array}$ & $\begin{array}{c}0.127^{* * *} * \\
(0.022)\end{array}$ & $\begin{array}{c}0.269^{* * *} \\
(0.029)\end{array}$ \\
\hline Year effects & Yes & Yes & Yes & Yes & Yes & Yes & Yes & Yes \\
\hline Nation effects & No & No & No & No & No & No & No & No \\
\hline Interaction vector & No & No & No & No & No & No & No & No \\
\hline Observations & 1493 & 1493 & 1493 & 1493 & 1493 & 1493 & 1493 & 1493 \\
\hline \multicolumn{9}{|c|}{$\begin{array}{l}\text { The dependent value takes a value of one for country i in year } t \text { if there is a politically motivated murder or } \\
\text { attempted murder of a high government official or politician (column }(1) \text { ), if there is a strike of } 1,000 \text { or more } \\
\text { industrial or service workers (column }(2) \text { ), if there is any armed activity, sabotage, or bombings carried on by } \\
\text { independent bands of citizens or irregular forces and aimed at the overthrow of the present regime (column }(3) \text { ), if } \\
\text { there is any rapidly developing situation that threatens to bring the downfall of the present regime (column }(4) \text { ), if } \\
\text { there is any systematic elimination by jailing or execution of political opposition within the ranks of the regime or } \\
\text { the opposition (column (5)), if the country experiences a violent demonstration or clash of more than } 100 \text { citizens } \\
\text { involving the use of physical force (column }(6) \text { ), if there is any illegal or forced change in the top government elite, } \\
\text { any attempt at such a change, or any successful or unsuccessful armed rebelion whose aim is independence from } \\
\text { the central government (column }(7) \text { ), and if there is any peaceful public gathering of at least } 100 \text { people for the } \\
\text { primary purpose of displaying or voicing their opposition to government policies or authority (column }(8) \text { ). All } \\
\text { equations include year fixed effects. Cluster-robust standard errors at the region level are in parentheses below the } \\
\text { estimated coefficients. * ** and *** denote statistical significance at the } 10 \%, 5 \% \text { and } 1 \% \text { levels. }\end{array}$} \\
\hline
\end{tabular}


Table 4: Social Unrest and Vulnerability to Revolution

Baseline Specification

\begin{tabular}{|c|c|c|c|c|c|c|c|c|}
\hline & $(1)$ & $(2)$ & (3) & (4) & $(5)$ & (6) & $(7)$ & $(8)$ \\
\hline$v_{i t}$ & $\begin{array}{l}0.008 \\
(0.019)\end{array}$ & $\begin{array}{c}-0.109^{* *} \\
(0.038)\end{array}$ & $\begin{array}{c}0.042^{* * *} \\
(0.010)\end{array}$ & $\begin{array}{l}-0.008 \\
(0.036)\end{array}$ & $\begin{array}{l}-0.014 \\
(0.009)\end{array}$ & $\begin{array}{c}-0.097^{* *} \\
(0.035)\end{array}$ & $\begin{array}{l}-0.033 \\
(0.036)\end{array}$ & $\begin{array}{c}-0.128^{* * *} \\
(0.023)\end{array}$ \\
\hline$B O P_{i t}$ & $\begin{array}{l}0.075 \\
(0.040)\end{array}$ & $\begin{array}{l}0.016 \\
(0.029)\end{array}$ & $\begin{array}{c}0.165^{* *} \\
(0.063)\end{array}$ & $\begin{array}{l}0.053 \\
(0.032)\end{array}$ & $\begin{array}{c}0.063^{*} \\
(0.028)\end{array}$ & $\begin{array}{c}0.083^{*} \\
(0.032)\end{array}$ & $\begin{array}{c}0.171^{* * *} \\
\quad(0.028)\end{array}$ & $\begin{array}{l}0.023 \\
(0.039)\end{array}$ \\
\hline Constant & $\begin{array}{c}0.173^{* * *} \\
(0.022)\end{array}$ & $\begin{array}{c}0.173^{* * *} \\
(0.016)\end{array}$ & $\begin{array}{c}0.163^{* * *} \\
(0.033)\end{array}$ & $\begin{array}{c}0.199 * * * \\
(0.024)\end{array}$ & $\begin{array}{c}0.090 * * * \\
(0.010)\end{array}$ & $\begin{array}{c}0.192^{* * *} \\
(0.026)\end{array}$ & $\begin{array}{c}0.127^{* * *} \\
(0.022)\end{array}$ & $\begin{array}{c}0.268^{* * *} \\
(0.030)\end{array}$ \\
\hline Year effects & Yes & Yes & Yes & Yes & Yes & Yes & Yes & Yes \\
\hline Nation effects & No & No & No & No & No & No & No & No \\
\hline Interaction vector & No & No & No & No & No & No & No & No \\
\hline Observations & 1459 & 1459 & 1459 & 1459 & 1459 & 1459 & 1459 & 1459 \\
\hline
\end{tabular}

This table presents estimates of equation (1). The dependent variable takes a value of one for country i in year t if there is a politically motivated murder or attempted murder of a high government official or politician (column (1)), if there is a strike of 1,000 or more industrial or service workers (column (2)), if there is any armed activity, sabotage, or bombings carried on by independent bands of citizens or irregular forces and aimed at the overthrow of the present regime (column (3)), if there is any rapidly developing situation that threatens to bring the downfall of the present regime (column (4)), if there is any systematic elimination by jailing or execution of political opposition within the ranks of the regime or the opposition (column (5)), if the country experiences a violent demonstration or clash of more than 100 citizens involving the use of physical force (column (6)), if there is any illegal or forced change in the top government elite, any attempt at such a change, or any successful or unsuccessful armed rebelion whose aim is independence from the central government (column (7)), and if there is any peaceful public gathering of at least 100 people for the primary purpose of displaying or voicing their opposition to government policies or authority (column (8)). All equations include year fixed effects. Cluster-robust standard errors at the region level are in parentheses below the estimated coefficients. ${ }^{*},{ }^{*}$ and ${ }^{* * *}$ denote statistical significance at the $10 \%, 5 \%$ and $1 \%$ levels. 


\section{(1)}

\begin{tabular}{|c|c|c|c|c|c|c|c|c|}
\hline$v_{i t}$ & $\begin{array}{c}0.365^{* * *} \\
(0.032)\end{array}$ & $\begin{array}{c}0.279^{* * *} \\
(0.013)\end{array}$ & $\begin{array}{c}0.333^{* * *} \\
(0.009)\end{array}$ & $\begin{array}{l}0.120^{*} \\
(0.059)\end{array}$ & $\begin{array}{c}0.232^{* * *} \\
(0.010)\end{array}$ & $\begin{array}{c}0.221^{* * *} \\
(0.043)\end{array}$ & $\begin{array}{c}0.298 * * * \\
(0.030)\end{array}$ & $\begin{array}{c}0.026 \\
(0.108)\end{array}$ \\
\hline$B O P_{i t}$ & $\begin{array}{c}0.520^{* *} \\
(0.131)\end{array}$ & $\begin{array}{c}0.271 \\
(0.334)\end{array}$ & $\begin{array}{c}0.993^{*} \\
(0.463)\end{array}$ & $\begin{array}{l}-0.034 \\
(0.538)\end{array}$ & $\begin{array}{l}-0.095 \\
(0.348)\end{array}$ & $\begin{array}{c}0.302 \\
(0.336)\end{array}$ & $\begin{array}{c}0.724^{* * *} \\
(0.122)\end{array}$ & $\begin{array}{c}0.278 \\
(0.473)\end{array}$ \\
\hline$C_{i t}$ & $\begin{array}{l}0.266 \\
(0.224)\end{array}$ & $\begin{array}{l}0.056 \\
(0.393)\end{array}$ & $\begin{array}{c}0.221 \\
(0.337)\end{array}$ & $\begin{array}{l}-0.278 \\
(0.243)\end{array}$ & $\begin{array}{l}0.158 \\
(0.298)\end{array}$ & $\begin{array}{l}-0.042 \\
(0.313)\end{array}$ & $\begin{array}{l}0.120 \\
(0.272)\end{array}$ & $\begin{array}{c}0.476 \\
(0.449)\end{array}$ \\
\hline$B_{i t}$ & $\begin{array}{l}0.082 \\
(0.044)\end{array}$ & $\begin{array}{l}0.008 \\
(0.064)\end{array}$ & $\begin{array}{l}-0.008 \\
(0.043)\end{array}$ & $\begin{array}{l}-0.043 \\
(0.041)\end{array}$ & $\begin{array}{l}0.023 \\
(0.049)\end{array}$ & $\begin{array}{l}-0.026 \\
(0.064)\end{array}$ & $\begin{array}{c}0.089 * * \\
(0.029)\end{array}$ & $\begin{array}{l}0.092 \\
(0.080)\end{array}$ \\
\hline$O_{i t}$ & $\begin{array}{l}0.227 \\
(0.250)\end{array}$ & $\begin{array}{l}0.047 \\
(0.411)\end{array}$ & $\begin{array}{l}-0.354 \\
(0.251)\end{array}$ & $\begin{array}{l}-0.570 \\
(0.394)\end{array}$ & $\begin{array}{l}-0.092 \\
(0.428)\end{array}$ & $\begin{array}{l}-0.268 \\
(0.417)\end{array}$ & $\begin{array}{l}0.138 \\
(0.267)\end{array}$ & $\begin{array}{c}0.364 \\
(0.557)\end{array}$ \\
\hline Year effects & Yes & Yes & Yes & Yes & Yes & Yes & Yes & Yes \\
\hline Nation effects & Yes & Yes & Yes & Yes & Yes & Yes & Yes & Yes \\
\hline Interaction vector & Yes & Yes & Yes & Yes & Yes & Yes & Yes & Yes \\
\hline Observations & 1459 & 1459 & 1459 & 1459 & 1459 & 1459 & 1459 & 1459 \\
\hline Number of id & 83 & 83 & 83 & 83 & 83 & 83 & 83 & 83 \\
\hline
\end{tabular}

The dependent value takes a value of one for country $\mathrm{i}$ in year $\mathrm{t}$ if there is a politically motivated murder or attempted murder of a high government official or politician (column (1)), if there is a strike of 1,000 or more industrial or service workers (column (2)), if there is any armed activity, sabotage, or bombings carried on by independent bands of citizens or irregular forces and aimed at the overthrow of the present regime (column (3)), if there is any rapidly developing situation that threatens to bring the downfall of the present regime (column (4)), if there is any systematic elimination within the ranks of the regime or the opposition (column (5)), if the country experiences a violent demonstration or clash of more than 100 citizens involving force force (column (6)), if there is any illegal or forced change in the top government elite, any attempt at such a change, or any successful or unsuccessful armed rebelion whose aim is independence from the central government (column (7)), and if there is any peaceful public gathering of at least 100 people opposing the government (column (8)). All equations include year and country-specific fixed effects. Cluster-robust standard errors at the region level are in parentheses below the estimated coefficients. ${ }^{*}, * *$ and ${ }^{* * *}$ denote statistical significance at the $10 \%, 5 \%$ and $1 \%$ levels. 
Table 6. Social Unrest and Vulnerability to Revolution

Adding Country Effects, Control Variables, GDP and GDP Per Capita

\begin{tabular}{|c|c|c|c|c|c|c|c|c|}
\hline & $(1)$ & $(2)$ & $(3)$ & $(4)$ & $(5)$ & $(6)$ & $(7)$ & (8) \\
\hline$v_{i t}$ & $\begin{array}{c}0.316^{* * *} \\
(0.022)\end{array}$ & $\begin{array}{c}0.212^{* * *} \\
(0.026)\end{array}$ & $\begin{array}{c}0.265^{* * *} \\
(0.025)\end{array}$ & $\begin{array}{l}0.110^{*} \\
(0.051)\end{array}$ & $\begin{array}{c}0.240^{* * *} \\
(0.056)\end{array}$ & $\begin{array}{c}0.244^{* * *} \\
(0.032)\end{array}$ & $\begin{array}{c}0.203^{* * *} \\
(0.045)\end{array}$ & $\begin{array}{l}-0.049 \\
(0.075)\end{array}$ \\
\hline$B O P_{i t}$ & $\begin{array}{c}0.700 * * * \\
(0.115)\end{array}$ & $\begin{array}{c}0.229 \\
(0.289)\end{array}$ & $\begin{array}{l}1.235^{*} \\
(0.593)\end{array}$ & $\begin{array}{l}0.118 \\
(0.405)\end{array}$ & $\begin{array}{c}0.166 \\
(0.230)\end{array}$ & $\begin{array}{c}0.513^{*} \\
(0.211)\end{array}$ & $\begin{array}{c}0.912^{* *} \\
(0.261)\end{array}$ & $\begin{array}{l}0.452 \\
(0.436)\end{array}$ \\
\hline$C_{i t}$ & $\begin{array}{l}0.328 \\
(0.191)\end{array}$ & $\begin{array}{l}0.028 \\
(0.382)\end{array}$ & $\begin{array}{l}0.323 \\
(0.305)\end{array}$ & $\begin{array}{l}-0.272 \\
(0.145)\end{array}$ & $\begin{array}{c}0.292 \\
(0.255)\end{array}$ & $\begin{array}{c}0.102 \\
(0.294)\end{array}$ & $\begin{array}{l}0.098 \\
(0.307)\end{array}$ & $\begin{array}{l}0.511 \\
(0.381)\end{array}$ \\
\hline$B_{i t}$ & $\begin{array}{l}0.055 \\
(0.124)\end{array}$ & $\begin{array}{l}-0.063 \\
(0.102)\end{array}$ & $\begin{array}{l}-0.032 \\
(0.063)\end{array}$ & $\begin{array}{c}-0.122^{* *} \\
(0.044)\end{array}$ & $\begin{array}{c}0.022 \\
(0.120)\end{array}$ & $\begin{array}{l}0.009 \\
(0.093)\end{array}$ & $\begin{array}{l}-0.009 \\
(0.118)\end{array}$ & $\begin{array}{l}0.084 \\
(0.082)\end{array}$ \\
\hline$O_{i t}$ & $\begin{array}{l}0.228 \\
(0.262)\end{array}$ & $\begin{array}{l}-0.017 \\
(0.432)\end{array}$ & $\begin{array}{l}-0.115 \\
(0.219)\end{array}$ & $\begin{array}{c}-0.664^{* * *} \\
(0.140)\end{array}$ & $\begin{array}{c}0.138 \\
(0.318)\end{array}$ & $\begin{array}{c}0.124 \\
(0.379)\end{array}$ & $\begin{array}{l}-0.109 \\
(0.217)\end{array}$ & $\begin{array}{l}0.370 \\
(0.386)\end{array}$ \\
\hline$G D P_{i t}$ & $\begin{array}{l}-0.034 \\
(0.108)\end{array}$ & $\begin{array}{l}-0.051 \\
(0.084)\end{array}$ & $\begin{array}{l}-0.105 \\
(0.078)\end{array}$ & $\begin{array}{l}0.083 \\
(0.045)\end{array}$ & $\begin{array}{l}0.034 \\
(0.132)\end{array}$ & $\begin{array}{l}0.006 \\
(0.089)\end{array}$ & $\begin{array}{l}0.003 \\
(0.108)\end{array}$ & $\begin{array}{l}-0.072 \\
(0.050)\end{array}$ \\
\hline$G D P_{i t} / N_{i t}$ & $\begin{array}{l}0.007 \\
(0.076)\end{array}$ & $\begin{array}{c}0.032 \\
(0.029)\end{array}$ & $\begin{array}{l}0.172 \\
(0.098)\end{array}$ & $\begin{array}{l}-0.075 \\
(0.072)\end{array}$ & $\begin{array}{l}0.057 \\
(0.048)\end{array}$ & $\begin{array}{l}0.147 \\
(0.086)\end{array}$ & $\begin{array}{l}-0.085 \\
(0.045)\end{array}$ & $\begin{array}{l}0.027 \\
(0.106)\end{array}$ \\
\hline Year effects & Yes & Yes & Yes & Yes & Yes & Yes & Yes & Yes \\
\hline Nation effects & Yes & Yes & Yes & Yes & Yes & Yes & Yes & Yes \\
\hline Interaction vector & Yes & Yes & Yes & Yes & Yes & Yes & Yes & Yes \\
\hline Observations & 1459 & 1459 & 1459 & 1459 & 1459 & 1459 & 1459 & 1459 \\
\hline Number of id & 83 & 83 & 83 & 83 & 83 & 83 & 83 & 83 \\
\hline
\end{tabular}

The dependent value takes a value of one for country $\mathrm{i}$ in year $\mathrm{t}$ if there is a politically motivated murder or attempted murder of a high government official or politician (column (1)), if there is a strike of 1,000 or more industrial or service workers (column (2)), if there is any armed activity, sabotage, or bombings carried on by independent bands of citizens or irregular forces and aimed at the overthrow of the present regime (column (3)), if there is any rapidly developing situation that threatens to bring the downfall of the present regime (column (4)), if there is any systematic elimination within the ranks of the regime or the opposition (column (5)), if the country experiences a violent demonstration or clash of more than 100 citizens involving force force (column (6)), if there is any illegal or forced change in the top government elite, any attempt at such a change, or any successful or unsuccessful armed rebelion whose aim is independence from the central government (column (7)), and if there is any peaceful public gathering of at least 100 people opposing the government (column (8)). All equations include year and country-specific fixed effects. Cluster-robust standard errors at the region level are in parentheses below the estimated coefficients. ${ }^{*}, * *$ and ${ }^{* * *}$ denote statistical significance at the $10 \%, 5 \%$ and $1 \%$ levels. 